\title{
Depth-hoar crystal growth in the surface layer under high temperature gradient
}

\author{
Takuya Fukuzawa and Eizi Akitaya \\ Institute of Low Temperature Science, Hokkaido University, Sapporo 060, Japan
}

\begin{abstract}
The quick growth of depth-hoar crystals was observed at nighttime just below the snow surface on a south-facing slope. This growth was due to a high temperature gradient $\left(>100 \mathrm{~K} \mathrm{~m}^{-1}\right)$ near the snow surface under clear skies after a thin deposition of new snow on older and denser snow. The temperature gradient was greater when internal melting had taken place during daytime, keeping the sub-surface snow temperature at $0^{\circ} \mathrm{C}$ even after sunset until all liquid water had frozen. To understand the relationship between the crystal growth rate and the temperature gradient, a series of experiments was carried out in the laboratory. The snow sample was set under a constant temperature gradient between 100 and $300 \mathrm{~K} \mathrm{~m}^{-1}$ and sustained for about $50 \mathrm{~h}$. The average crystal size increased linearly with time and the crystal growth rate increased as the given temperature gradient increased. The growth rates were in the order of $10^{-9} \mathrm{~m} \mathrm{~s}^{-1}$, which gave a good agreement with the results of the field observation.
\end{abstract}

\section{INTRODUCTION}

The seasonal snow cover has often been treated as a homogeneous medium, though it is highly stratified with many layers. Each layer has its own physical properties due to the initial snow condition at the time of deposition on the previous surface and the subsequent metamorphosis, which is mainly determined by the varying temperature field, load and arrangement of ice particles in the layer.

A layer with relatively low strength plays an important role in a slab-avalanche release. The kinetic growth metamorphism produces a depth-hoar layer, which is typically weak because of thin bonds between particles. Accordingly, depth-hoar crystals have long been of interest in avalanche studies.

Most studies on depth-hoar crystals have dealt with the basal part of a snow cover because the crystals have been frequently observed there. Therefore, previous experiments on kinetic growth metamorphism were performed for high-density snow $\left(>180 \mathrm{~kg} \mathrm{~m}^{-3}\right)$, under low temperature gradients of $<100 \mathrm{~K} \mathrm{~m}^{-1}$ on a time scale of several tens of days. Akitaya (1974) made a precise experiment in the cold laboratory on the morphology of depth-hoar crystals and constructed a diagram relating crystal shapes to temperature and temperature gradient. Marbouty (1980) determined the growth-rate dependency on temperature, temperature gradient and snow density. Both researchers executed their experiments under the conditions typical of basal layer.

However, lower snow density and higher temperature gradients may be found near the snow surface, where the temperature field is highly fluctuating due to exposure to the ambient air temperature. These conditions may produce depth-hoar crystals in a short period. Actually, Akitaya and Shimizu (1987) found depth-hoar crystals in the layer beneath the snow surface. Colbeck (1989) simulated the high growth rate of faceted crystals near the surface.

In this study, field observations were carried out to examine how long it takes to metamorphose new-snow crystals to depth-hoar crystals near the surface. Also, a series of laboratory experiments were performed on kinetic growth metamorphism for low-density snow under high temperature gradients of $100-300 \mathrm{~K} \mathrm{~m}^{-1}$.

\section{SITE AND METHODS}

The observation site was a south-facing slope of $25^{\circ}$ at $240 \mathrm{~m}$ a.s.l., near the Institute of Low Temperature Science avalanche research station in Toikanbetsu, northern Hokkaido, Japan $\left(45^{\circ} \mathrm{N}, 142^{\circ} \mathrm{E}\right)$. Observations were made over 50 days during the winter of 1989-90.

Snow crystals from $1 \mathrm{~cm}$ depth were sampled carefully at sunset and sunrise, and often at other times during the night, and microscopic photographs were taken of the crystals scattered on glass. Temperatures of snow and air, incoming and outgoing shortwave radiaiton, net radiation, and wind speed were measured at the site. Snow temperatures were measured using thermocouples set every $2 \mathrm{~cm}$ from the surface to $8 \mathrm{~cm}$ depth, at 10 -minute intervals during the night. Amounts of incoming and outgoing shortwave radiation and net all-wave radiation were measured with pyranometers and a net radiometer. Windspeed was measured at $1.5 \mathrm{~m}$ with a 3-cup anemometer.

In order to characterize the crystal size, microscopic 
photographs were analyzed using an image analyzer. In this study, an average size $(d)$ of snow crystals was defined as mean diameter for circles, each of which had the same area as the projected area of each snow particle in the photographs, using more than 100 clearly visible single crystals. Overlapped crystals or complicated clusters were eliminated.

This analysis contains large errors. The average size for projected areas of crystals scattered at random does not correspond to average volume without direct measurement of mass or three-dimensional analysis. The average size for the group of thin and outspread crystals, e.g. well-grown dendrites, tends to be greater than that for solid crystals with the same volumes. However, it is practical to compare crystal sizes when their shapes are similar. In this study the crystal sizes were compared with the average size defined above, as few outspread crystals were observed visually.

\section{OBSERVATIONAL RESULTS AND DISGUSSION}

\section{An example in January}

Snow stratigraphy near the surface of the snow cover at the time of sunset $(1550 \mathrm{~h})$ on 23 January 1990 consisted of $3 \mathrm{~cm}$ of new snow on dry, lightly compacted snow. Densities of the two layers were 70 and $170 \mathrm{~kg} \mathrm{~m}^{-3}$, respectively.

Temperature data for 23-24 January are not shown due to measurement error. Figure la shows snowtemperature variation at each depth during the following night, 24-25 January. Three arrows indicate the times for sampling of snow crystals. There is a large difference in temperature between the surface and $2 \mathrm{~cm}$ depth. Temperature-gradient profiles at the times marked with vertical broken lines are shown in Figure $1 \mathrm{~b}$ assuming

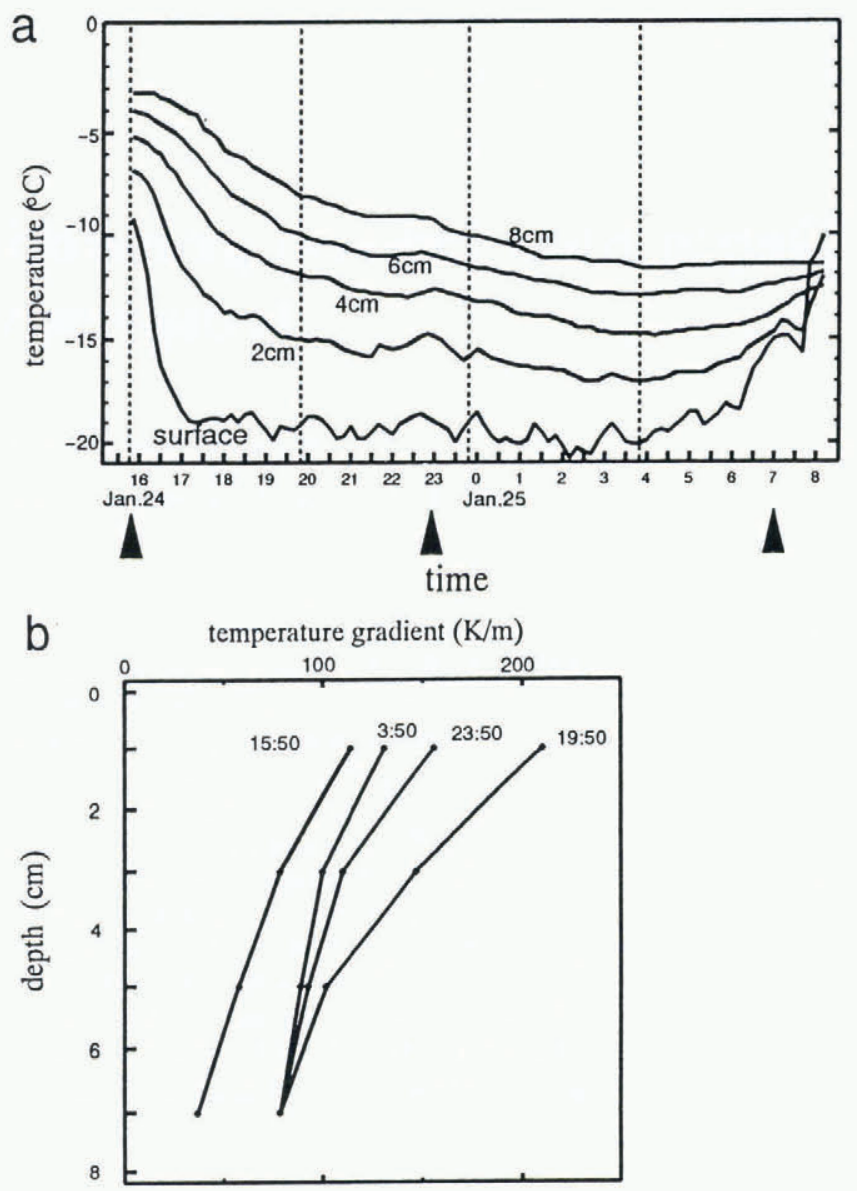

Fig. 1. a, snow-temperature variation with time at $2 \mathrm{~cm}$ intervals from the surface to $8 \mathrm{~cm}$ depth during the night of 24-25 January 1990; the arrows show sampling time. b, temperature-gradient profile at $4 \mathrm{~h}$ intervals.

linearity of temperature gradient between depths of thermocouples. Very high temperature gradients $\left(159 \mathrm{~K} \mathrm{~m}^{-1}\right.$ on average) can be seen beneath the snow
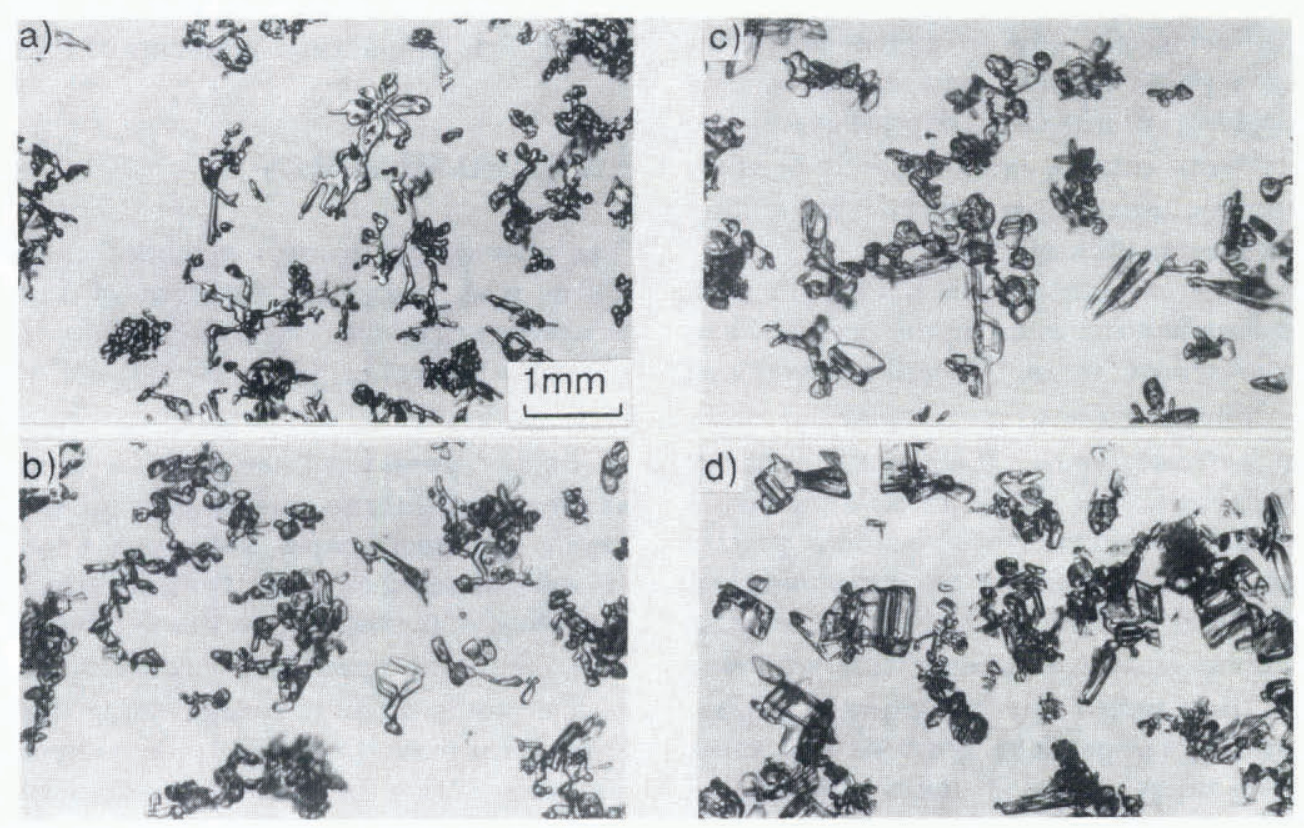

Fig. 2. Microscopic photographs of snow crystals sampled from $1 \mathrm{~cm}$ depth. a, new snow with many very small snow crystals at $1550 \mathrm{~h}, 23$ January 1990; $b$, fine faceted crystals of $d=0.20 \mathrm{~mm}$ at $1550 \mathrm{~h}, 24$ Fanuary; c, larger faceted crystals of $d=0.24 \mathrm{~mm}$ at $2300 \mathrm{~h}$; $d$, depth-hoar crystals with faceted crystals of $d=0.29 \mathrm{~mm}$ at $0700 \mathrm{~h}, 25 \mathrm{January}$. The growth rate is $1.65 \times 10^{-9} \mathrm{~ms}^{-1}$. 
surface through the night (Fig. 1b). The average snow temperature at $1 \mathrm{~cm}$ depth during the night was $-16.6^{\circ} \mathrm{C}$.

Microscopic photographs of snow crystals from $1 \mathrm{~cm}$ at $1550 \mathrm{~h}$ (sunset) of 23 January, $1550 \mathrm{~h}$ (sunset) and $2300 \mathrm{~h}$ of 24 January and $0700 \mathrm{~h}$ (sunrise) of 25 January are shown in Figure 2a-d. Figure 2a shows new crystals with very small snow particles; Figure $2 \mathrm{~b}$ shows small faceted crystals with average size $(d)$ of $0.20 \mathrm{~mm}$; Figure 2c shows solid faceted crystals $(d=0.24 \mathrm{~mm})$, and Figure $2 \mathrm{~d}$ shows larger depth-hoar crystals $(d=0.29 \mathrm{~mm})$. In this case new snow crystals metamorphosed into depth-hoar crystals during two nights. The growth rate was $1.65 \times 10^{-9} \mathrm{~m} \mathrm{~s}^{-1}$.

The sky was clear from the evening of 23 January until the morning of 25 January. Therefore, solar radiation was high on the south-facing slope during daytime and radiative cooling was also high during the night. Wind speed was low, averaging $1.0 \mathrm{~m} \mathrm{~s}^{-1}$.

\section{An example in March}

Snow stratigraphy near the surface at $1630 \mathrm{~h}$ (sunset) on 2 March 1990 consisted of $2 \mathrm{~cm}$ of new snow overlying older wet granular snow. Snow densities were 90 and $320 \mathrm{~kg} \mathrm{~m}^{-3}$, respectively. Water content of the snow at $3 \mathrm{~cm}$ depth was $8 \%$ by mass. The snow-temperature variation at each depth during the night of 2-3 March and temperature-gradient profiles at the times with

a

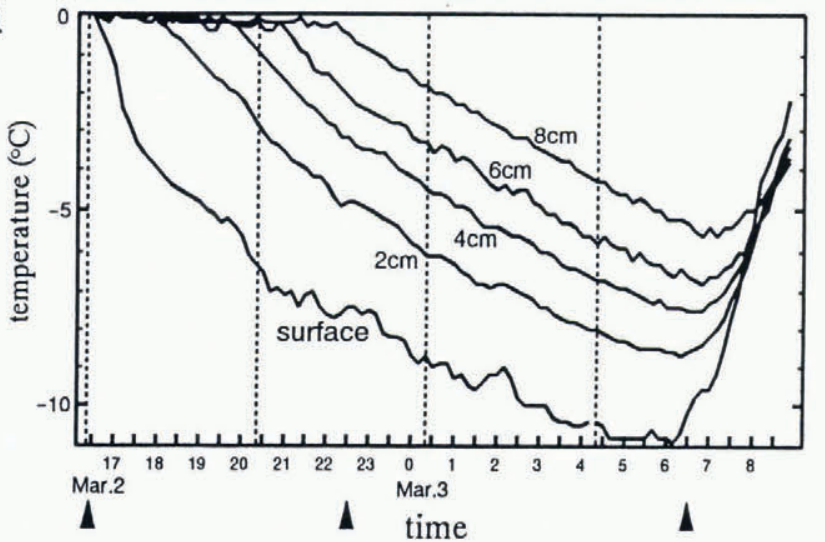

b temperature gradient $(\mathrm{K} / \mathrm{m})$

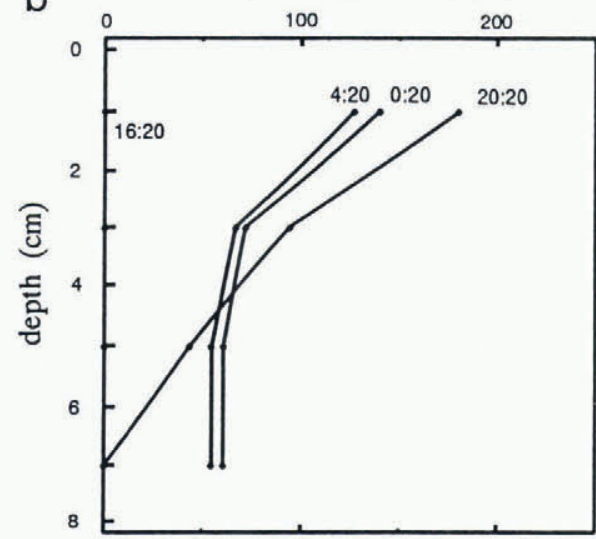

Fig.3. a, snow-temperature variation with time at $2 \mathrm{~cm}$ intervals from the surface to $8 \mathrm{~cm}$ depth during night of 2-3 March 1990; the arrows show sampling times; $b$, temperature-gradient profile at $4 \mathrm{~h}$ intervals.
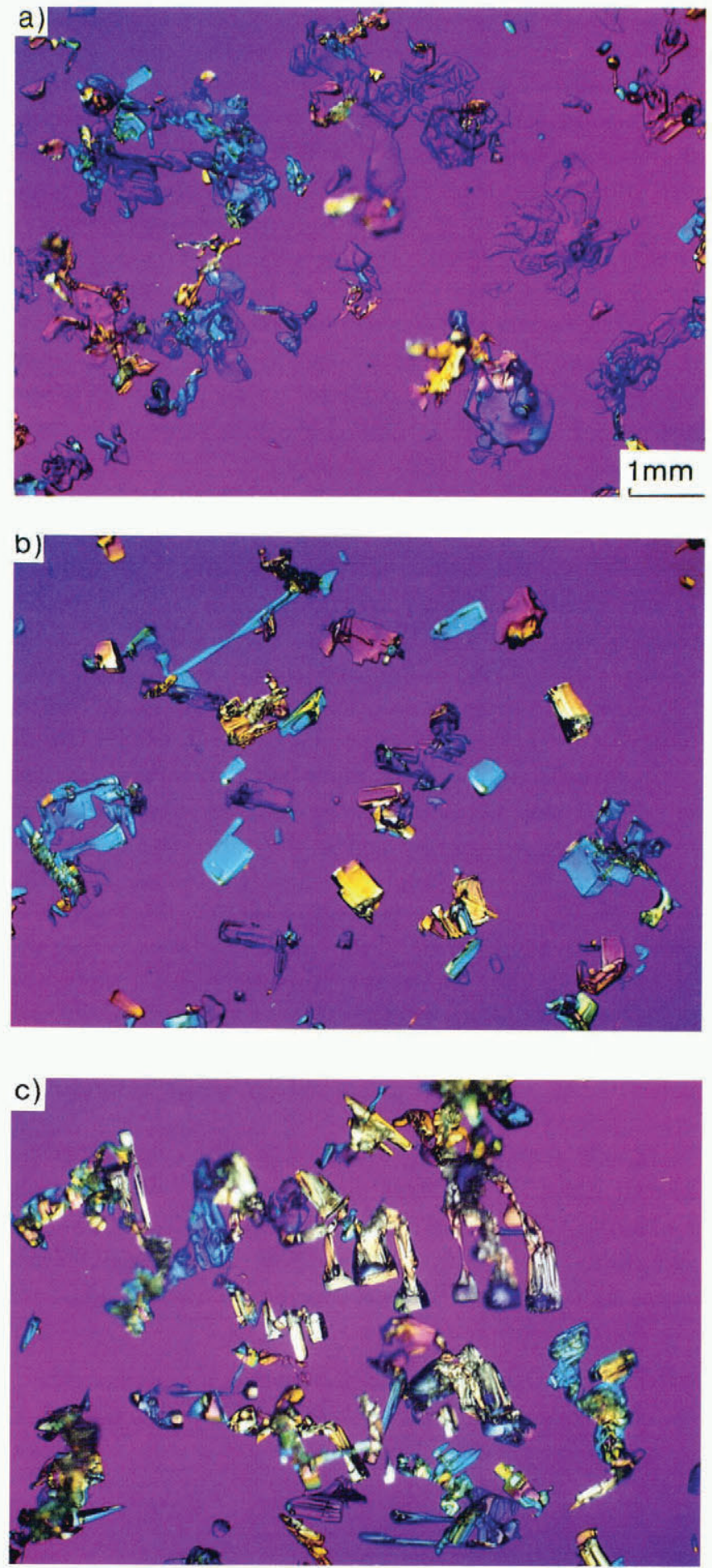

Fig. 4. Microscopic photographs of snow crystals sampled from $1 \mathrm{~cm}$ depth. a, new snow and very fine faceted crystals of $d=0.22 \mathrm{~mm}$ at $1620 \mathrm{~h}, 2 \mathrm{March} 1990 ; b$, fine faceted crystals of $d=0.31 \mathrm{~mm}$ at $22.30 \mathrm{~h}$; $\mathrm{c}$, depth-hoar crystals of $d=0.39 \mathrm{~mm}$ at $0630 \mathrm{~h}, 3 \mathrm{March}$. The growth rate is $3.33 \times 10^{-9} \mathrm{~m} \mathrm{~s}^{-1}$.

broken lines are shown in Figure $3 a$ and $b$, respectively. High temperature gradients can be seen near the surface. Particularly in the new-snow layer beneath the surface, very high temperature gradients $\left(143 \mathrm{~K} \mathrm{~m}^{-1}\right.$ on average) persisted for $14 \mathrm{~h}$ through the night.

Microscopic photographs of snow crystals from $1 \mathrm{~cm}$ depth at the times of sunset $(1620 \mathrm{~h})$ of 2 March, night $(2200 \mathrm{~h})$ and sunrise $(0630 \mathrm{~h})$ of $3 \mathrm{March}$ are given in Figure $4 \mathrm{a}, \mathrm{b}$ and $\mathrm{c}$, respectively. Figure $4 \mathrm{a}$ shows new 
snow crystals along with a few small faceted crystals $(d=$ $0.22 \mathrm{~mm}$ ). Following Armstrong (1981), these can be considered to have grown during the daytime. Figure $4 \mathrm{~b}$ shows solid faceted crystals $(d=0.31 \mathrm{~mm})$. Figure $4 \mathrm{c}$ shows depth-hoar crystals $(d=0.39 \mathrm{~mm})$ with maximum size of about $1 \mathrm{~mm}$. Thus, it is clear that new-snow crystals changed to depth-hoar crystals during one night. In this case, the growth rate was $3.33 \times 10^{-9} \mathrm{~m} \mathrm{~s}^{-1}$, which is about twice that obtained in January. Though the temperature gradient was slightly lower than in January, the average temperature of $-6.3^{\circ} \mathrm{C}$ at $1 \mathrm{~cm}$ depth was higher. Consequently, the higher vapor-density gradient and vapor diffusion enhanced the kinetic-growth metamorphism.

Fine weather persisted on 2-3 March and upward longwave radiation was high during the evening. Accordingly, the surface temperature decreased rapidly. Wind speed was low, averaging $0.8 \mathrm{~m} \mathrm{~s}^{-1}$. Internal melting was observed below the surface and wet snow persisted for several hours after sunset, influenced either by diurnal solar radiation (Yosida, 1960) or by warm temperature before the upper layer accumulated, or by both. While the snow surface temperature decreased rapidly, cooled by upward longwave radiation, internal snow temperatures remained at $0^{\circ} \mathrm{C}$ until the meltwater refroze, i.e. the phase-change effect. Thermal conductivity of low-density snow is small, therefore high temperature gradients persisted in the new-snow layer during the night. The higher the temperature near the surface, the higher vapor-density gradients and vapor diffusivity will be. Thus, the growth of depth-hoar crystals in the layer beneath the surface is promoted by steep temperature gradient and high temperature.

Quick depth-hoar growth was observed more in March than in January (see Table 1) in northern Hokkaido. March has more clear days with greater solar radiation, therefore internal melting can take place more often, causing high temperature gradients to persist for

Table 1. Observation date, metamorphism at $1 \mathrm{~cm}$ depth, and thickness of low-density layer. Symbols follow Colbeck and others (1990)

Observation date

Metamorphism

Thickness of at $1 \mathrm{~cm}$ depth low-density layer

$\mathrm{cm}$

\begin{tabular}{|c|c|c|c|c|}
\hline 25-26 Dec. 1989 & + & $\rightarrow$ & $\square, \Lambda$ & 2.0 \\
\hline 11-12 Jan. 1990 & + & $\rightarrow$ & $\square, \Lambda$ & 1.5 \\
\hline 23-24 Jan. 1990 & + & $\rightarrow$ & $\square,+$ & 3.0 \\
\hline 24-25 Jan. 1990 & $\square, \quad+$ & $\rightarrow$ & $\Lambda, \square$ & 3.0 \\
\hline 16-17 Feb. 1990 & + & $\rightarrow$ & $\square, \Lambda$ & 1.0 \\
\hline 2-3 Mar. 1990 &,$+ \square$ & $\rightarrow$ & $\Lambda$ & 2.0 \\
\hline 5-6 Mar. 1990 & 1 & $\rightarrow$ & $\Lambda$ & 1.0 \\
\hline 8-9 Mar. 1990 & + & $\rightarrow$ & $\square$ & 3.0 \\
\hline 9-10 Mar. 1990 & $\square$ & $\rightarrow$ & $\Lambda$ & 3.0 \\
\hline 13-14 Mar. 1990 & I, $\square$ & $\rightarrow$ & $\Lambda$ & 2.0 \\
\hline
\end{tabular}

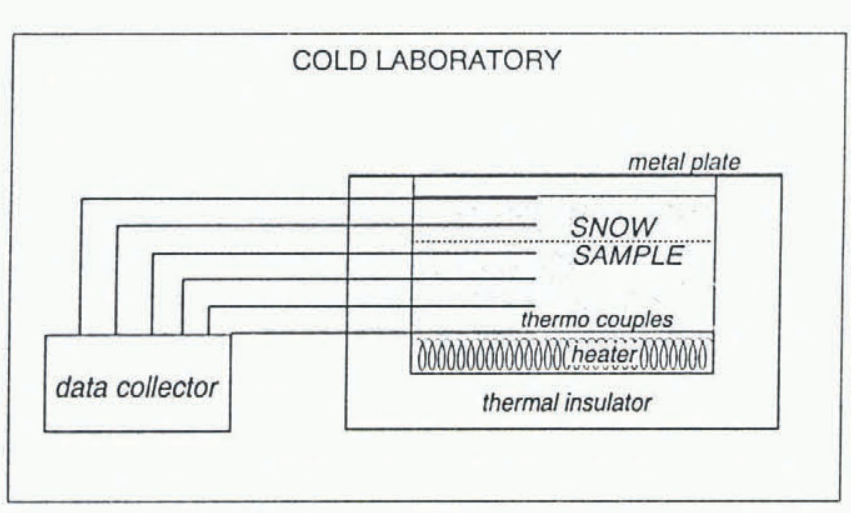

Fig. 5. Experimental device used in the laboratory.

long periods because of the phase-change effect. Because March has higher temperatures, larger vapor-density gradients appear near the snow surface.

The quick growth of depth hoar in the surface layer described above was observed in 10 out of 50 days during the observation period shown in Table 1 . In all cases, new snow metamorphosed to depth-hoar crystals in one or two nights.

\section{EXPERIMENTAL METHODS}

There is no experimental work on kinetic-growth metamorphism for the conditions that appear near the snow surface. Field observations show that high temperature gradients of $100-300 \mathrm{~K} \mathrm{~m}^{-1}$ promoted the growth of depth-hoar crystals in short periods in a low-density snow layer just below the surface. In previous experimental work, the maximum temperature gradient was $100 \mathrm{~K} \mathrm{~m}^{-1}$. To understand the relationship between growth rates and temperature gradients of large magnitude in low-density snow, a series of experiments was performed with various temperature gradients.

The experimental device used in the study is shown in Figure 5. A snow sample $0.4 \mathrm{~m}$ in length and width, less than $0.1 \mathrm{~m}$ in height, was placed in the insulated box and subjected to a predetermined temperature gradient. The sample was produced using an ice slicer. Textural homogeneity was ensured as much as possible by moving the sample box slowly during precipitation, promoting uniform and calm accumulation. Density of snow was adjustable from 80 to $450 \mathrm{~kg} \mathrm{~m}^{-3}$ by varying the level of blade of the slicer. Temperature profiles were monitored using thermocouples every $2 \mathrm{~cm}$ from the top to the bottom. These were maintained at the level within $1 \mathrm{~mm}$ by means of rigid tubes mounted in the insulator. Temperature at the bottom was controlled within $0.2^{\circ} \mathrm{C}$ by a thermoregulator. Temperature at the top was maintained within $1.5^{\circ} \mathrm{C}$ by changing room temperature. By regulating the temperatures and adjusting the height of the snow sample, the sample was subjected to a nearly constant temperature gradient for $50 \mathrm{~h}$.

In the series of experiments the temperature at $1 \mathrm{~cm}$ depth was maintained at $-16^{\circ} \mathrm{C}$ with accuracy of $1.5^{\circ} \mathrm{C}$. Low-density snow $\left(80-100 \mathrm{~kg} \mathrm{~m}^{-3}\right) 3 \mathrm{~cm}$ thick overlaid high-density snow $\left(300-340 \mathrm{~kg} \mathrm{~m}^{-3}\right)$ less than $7 \mathrm{~cm}$ thick. Temperature gradient in the upper layer was varied every $50 \mathrm{~K} \mathrm{~m}^{-1}$ from 100 to $300 \mathrm{~K} \mathrm{~m}^{-1}$. 
During an experiment snow crystals were sampled from $1 \mathrm{~cm}$ depth, and microscopic photographs of them scattered on the glass were taken repeatedly. A mean crystal size was determined in the way described above.

\section{EXPERIMENTAL RESULTS}

Microscopic photographs resulting from an experiment with a temperature gradient of $150 \mathrm{~K} \mathrm{~m}^{-1}$ are shown in Figure $6 \mathrm{a}-\mathrm{d}$. The original snow sample consisted of a large number of very fine ice particles (Fig. 6a) which metamorphosed to small faceted crystals (Fig. 6b) with average size $(d) 0.20 \mathrm{~mm}$ in the first $16 \mathrm{~h}$. The crystals metamorphosed further to depth-hoar crystals $(d=0.26 \mathrm{~mm})$ (Fig. 6c) in $24 \mathrm{~h}$ and finally to larger depth-hoar crystals $(d=0.39 \mathrm{~mm})$ (Fig. $6 \mathrm{~d})$ in $48 \mathrm{~h}$. From these measurements it is clear that a temperature gradient of $150 \mathrm{~K} \mathrm{~m}^{-1}$ caused the growth of depth-hoar crystals in two days in the layer of low-density snow.

The results of this series of experiments is shown in Figure 7 and their statistics are shown in Table 2. Average size increases linearly with time in an experiment for each temperature gradient. When a growth rate is defined as the gradient of regression line in Figure 7, determined with the least-square method, growth rate increases as given temperature gradient increases, as shown in Figure 8. This result is inconsistent with Marbouty's (1980) finding that there is an upper limit to growth rate at a temperature gradient of $100 \mathrm{~K} \mathrm{~m}^{-1}$.

\section{DISCUSSION}

Growth rates in the laboratory experiments are consistent with the rates observed in the field. The density of snow,

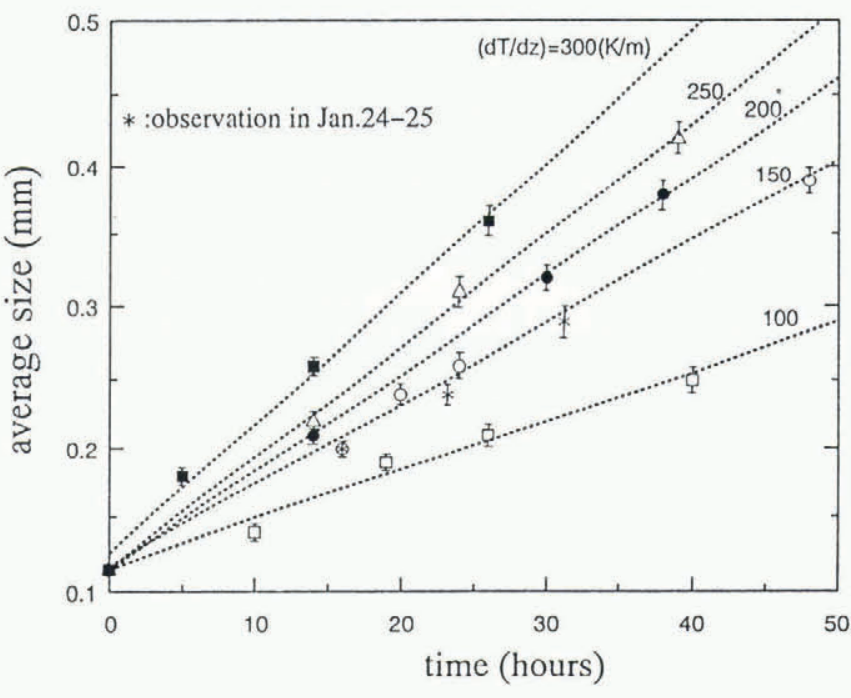

Fig. 7. Experimental results. Crystal average size versus time at a constant temperature of $-16^{\circ} \mathrm{C}$ and snow density of $80-100 \mathrm{~kg} \mathrm{~m}^{-3}$, with temperature gradients at $50 \mathrm{~K} \mathrm{~m}^{-1}$ intervals between 100 and $300 \mathrm{~K} \mathrm{~m}^{-1}$. Bars show statistical error of the average size, asterisks show the average sizes observed during the night of 24-25 January.

temperature and temperature gradient observed during 24-25 January are similar to those of the experiment for temperature gradient of $150 \mathrm{~K} \mathrm{~m}^{-1}$. Average sizes observed in the field 24-25 January are also shown in Figure 7 , though data for March are not shown due to inconsistencies in temperature. In Figure 7 the 16th hour of elapsed time in the experiment is adjusted to $1550 \mathrm{~h}, 24$ January, because the average sizes and metamorphism stages of these times are comparable. The experimental result for $150 \mathrm{~K} \mathrm{~m}^{-1}$ is consistent with observed average-size variation, hence, the growth rate in
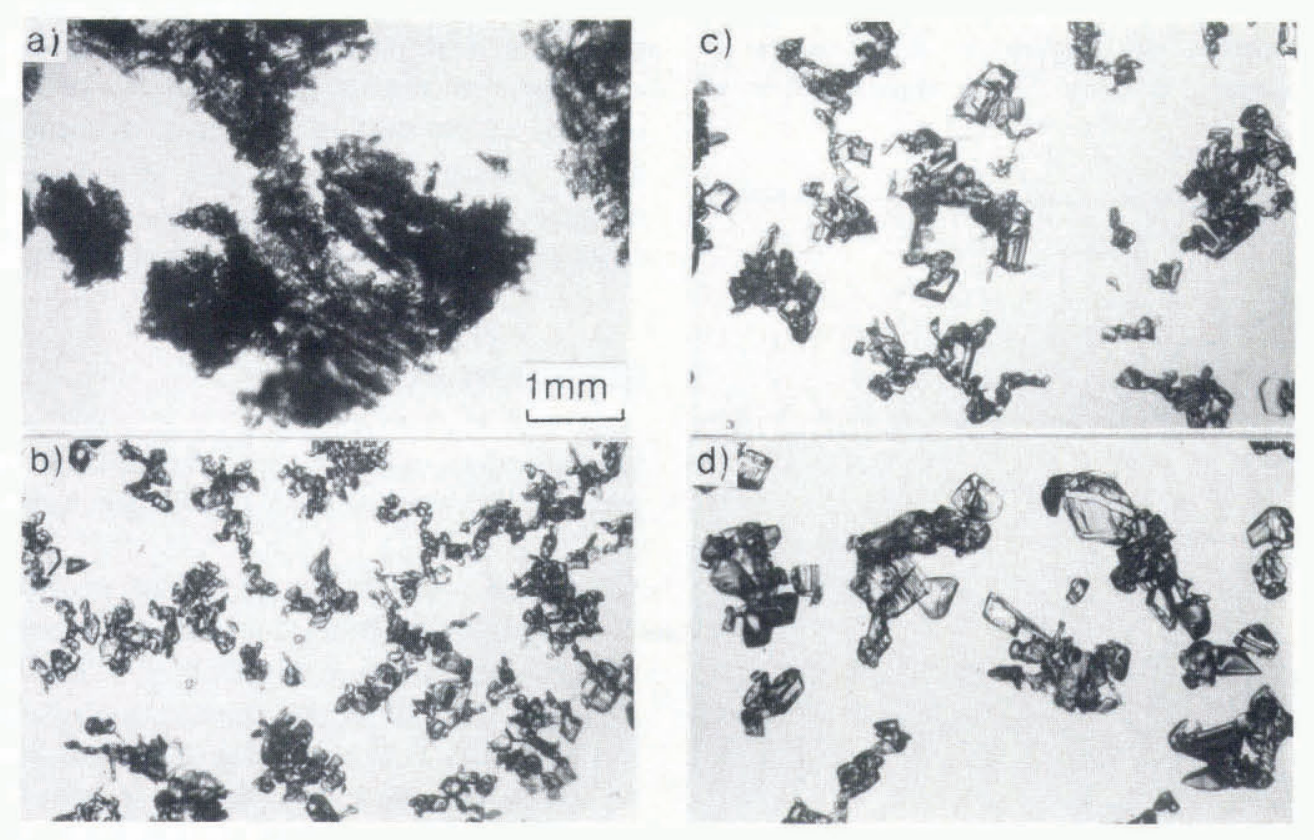

Fig. 6. Microscopic photographs of snow crystals sampled from $1 \mathrm{~cm}$ depth in the experiment with temperature gradient of $150 \mathrm{~K} \mathrm{~m}^{-1}$. a, slices of many very fine ice particles at start time; $b$, fine faceted crystals of $d=0.20 \mathrm{~mm}$ after $16 \mathrm{~h} ; c$, larger faceted crystals of $d=0.26 \mathrm{~mm}$ after $24 \mathrm{~h}$; $d$, depth-hoar crystals of $d=0.39 \mathrm{~mm}$ after $48 \mathrm{~h}$. 
Fukuzawa and Akitaya: Depth-hoar crystal growth

Table 2. Statistics of image-analysis results

Temperature gradient Elapse time Average size Standard deviation Crystal numbers Statistical error Growth rate
$\mathrm{K} \mathrm{m}^{-1}$
$\mathrm{h}$
$\mathrm{d}(\mathrm{mm})$
$\mathrm{s}(\mathrm{mm})$
N
$\mathrm{d} / \sqrt{\mathrm{N}}(\mathrm{mm}) \quad 10^{-9} \mathrm{~m} \mathrm{~s}^{-1}$

\begin{tabular}{|c|c|c|c|c|c|c|}
\hline - & 0 & 0.12 & 0.06 & 369 & 0.00312 & - \\
\hline \multirow{3}{*}{$300 \pm 10$} & 5 & 0.18 & 0.06 & 186 & 0.00439 & \multirow[b]{3}{*}{2.564} \\
\hline & 14 & 0.26 & 0.09 & 140 & 0.00760 & \\
\hline & 26 & 0.37 & 0.11 & 118 & 0.01012 & \\
\hline \multirow{3}{*}{$250 \pm 10$} & 14 & 0.22 & 0.08 & 240 & 0.00516 & \multirow[b]{3}{*}{2.188} \\
\hline & 24 & 0.31 & 0.11 & 168 & 0.00848 & \\
\hline & 39 & 0.42 & 0.16 & 138 & 0.01362 & \\
\hline \multirow{3}{*}{$200 \pm 10$} & 14 & 0.21 & 0.06 & 168 & 0.00462 & \multirow[b]{3}{*}{1.928} \\
\hline & 30 & 0.32 & 0.1 & 156 & 0.00800 & \\
\hline & 38 & 0.38 & 0.12 & 116 & 0.01114 & \\
\hline \multirow{4}{*}{$150 \pm 10$} & 16 & 0.20 & 0.06 & 230 & 0.00395 & \multirow[b]{4}{*}{1.600} \\
\hline & 20 & 0.24 & 0.06 & 172 & 0.00457 & \\
\hline & 24 & 0.26 & 0.09 & 122 & 0.00814 & \\
\hline & 48 & 0.39 & 0.11 & 124 & 0.00987 & \\
\hline \multirow{4}{*}{$100 \pm 10$} & 10 & 0.14 & 0.06 & 186 & 0.00439 & \multirow[b]{4}{*}{0.976} \\
\hline & 19 & 0.19 & 0.07 & 180 & 0.00521 & \\
\hline & 26 & 0.21 & 0.09 & 166 & 0.00698 & \\
\hline & 40 & 0.25 & 0.1 & 140 & 0.00845 & \\
\hline 159 & 16 & 0.20 & 0.07 & 124 & 0.00628 & \\
\hline$(24-25$ & 23.2 & 0.24 & 0.09 & 137 & 0.00768 & \\
\hline January) & 31.2 & 0.29 & 0.11 & 120 & 0.01004 & 1.647 \\
\hline
\end{tabular}

the experiment is also consistent with that in field observation, as shown in Figure 8. This series of experiments, however, is only for a temperature of

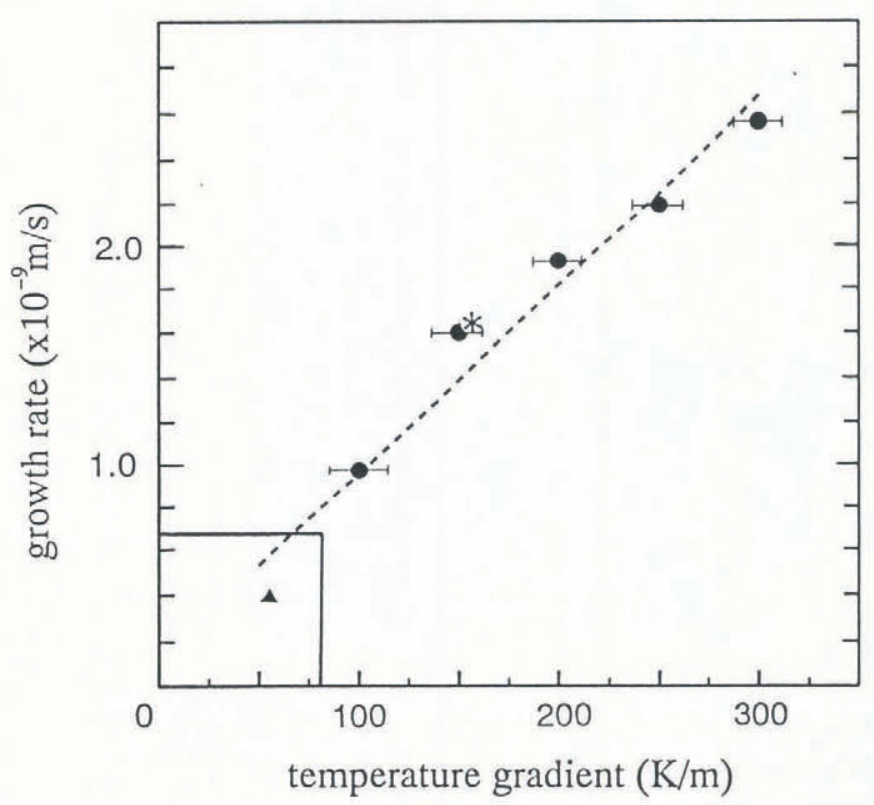

$-16^{\circ} \mathrm{C}$. Extensive experiments at high temperature gradients with various temperatures are needed to evaluate experimentally the growth rate of snow crystals induced in the near-surface layer of a snow cover. Also, direct measurement of mass of crystals and threedimensional analysis are necessary to derive mass growth rates from the average size defined in this study.

\section{CONCLUSION}

Observations showed that depth-hoar crystals were produced in one or two nights just below the surface

$\checkmark$ Fig. 8. Growth rate of faceted crystals for various temperature gradients at a constant temperature of $-16^{\circ} \mathrm{C}$ and snow density of $80-100 \mathrm{~kg} \mathrm{~m}^{-3}$. The box shows the range of kinetic growth metamorphism experiments carried out so far. Solid circles show experimental results in this study, bars show the accuracy of applied temperature gradient. The asterisk denotes growth rate during the night of 24-25 January and the solid triangle is from Marbouty's (1980) experiment for temperature of $-18^{\circ} \mathrm{C}$ and density of $180 \mathrm{~kg} \mathrm{~m}^{-3}$. 


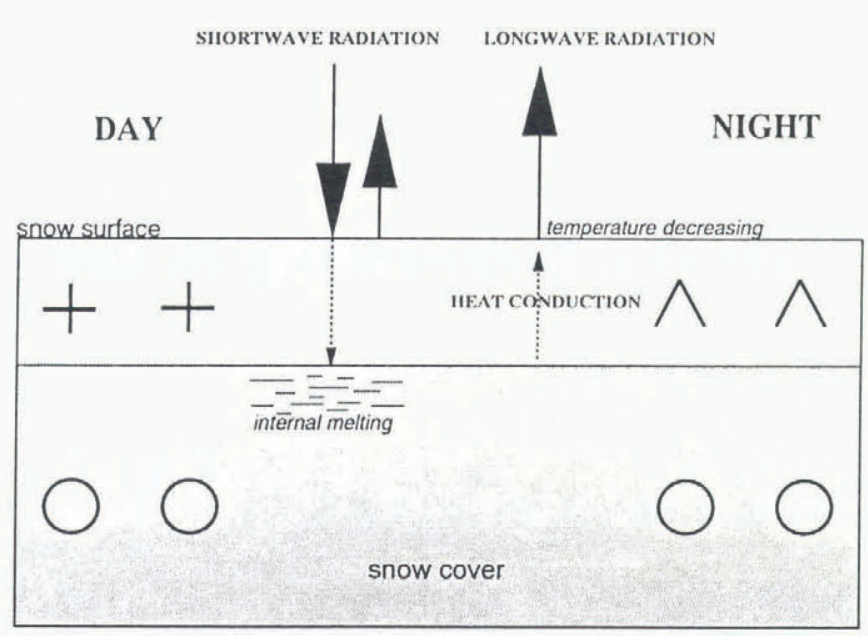

Fig. 9. Schematic diagram for the mechanism of quick growth of depth-hoar crystals in the surface layer.

under the conditions shown schematically in Figure 9. The first condition was that a low-density layer less than $3 \mathrm{~cm}$ thick overlay an older and denser snow layer with more radiation absorptivity. The second condition was that the temperature of sub-surface snow increased within the snow cover on the south-facing slope due to diurnal solar radiation, or timely snowfall on warmer old snow. The third condition was that surface temperature decreased rapidly due to upward longwave radiation under calm and clear weather during the night. As a result of these process, a high temperature gradient developed in the new snow and promoted the growth of crystals in the low-density layer.

A series of experiments showed high growth rate under high temperature gradients. The snow-crystal average size increased linearly with time under a constant temperature gradient and its growth rate increased as the given temperature gradient increased, although previous experimental work set an upper-limit value around the temperature gradient of $100 \mathrm{~K} \mathrm{~m}^{-1}$. The growth rate was in the order of $10^{-9} \mathrm{~m} \mathrm{~s}^{-1}$. These values of growth rate compared reasonably with values observed in the field. More experiments are needed with a range of temperatures and temperature gradients.

If internal melting exists it promotes the growth of depth hoar due to the phase-change effect and strong dependence of vapor-pressure gradient and diffusivity on temperature. In northern Hokkaido, snow and weather conditions described above are more common in early spring than in midwinter. When such conditions are present, quick growth of depth hoar takes place just below the surface. Avalanche danger will be high if the metamorphosed layer is covered by heavy snow in a later storm.

\section{ACKNOWLEDGEMENT}

This study was made possible by the fund for avalanche research of the Ministry of Education, Japan.

\section{REFERENCES}

Akitaya, E. 1974. Studies on depth hoar. Contrib. Inst. Low Temp. Sci., Ser. A 26.

Akitaya, E. and H. Shimizu. 1987. Observations of weak layers in a snow cover. Low Temp. Sci., Ser. A 46, 67-75. [In Japanese with English summary.]

Armstrong, R. L. 1981. Some observations on snowcover temperature patterns. Natl. Res. Counc. Can. Associate Committee on Geotechnical Research, Tech. Memo. 133, 6681.

Colbeck, S. C. 1989. Snow-crystal growth with varying surface temperatures and radiation penetration. $\mathcal{F}$. Glaciol., 35(119), 23-29.

Colbeck, S.C. and 7 others. 1990. The international classification for seasonal snow on the ground. Wallingford, Oxfordshire, International Association of Hydrological Sciences. International Commission on Snow and Ice.

Marbouty, D. 1980. An experimental study of temperature-gradient metamorphism. F. Glaciol., 26(94), 303312.

Yosida, Z. 1960. Internal melting of snow due to the penetrating sunlight. Low Temp. Sci., Ser. A 19, 97-111. [In Japanese with English summary.]

The accuracy of references in the text and in this list is the responsibility of the authors, to whom queries should be addressed. 